\title{
BEYOND THE HIJAB: SUBJECTIVE EXPERIENCES OF INDONESIAN MUSLIMAH BASKETBALL PLAYERS
}

\author{
Dwi Cahyo Kartiko ${ }^{1}$ and Deny Efita $\mathcal{N} u r$ Rakhmawati ${ }^{2}$ \\ ${ }^{1}$ Universitas Negeri Surabaya \\ ${ }^{2}$ UIN Maulana Malik Ibrahim Malang \\ Email: dwicahyo@unesa.ac.id
}

\section{Abstract}

This study aimed to explore the negotiation of Islam identity reflected from the hijabi basketball players' subjective experiences in Indonesia. A qualitative method was conducted from a subjectivist epistemological position. Six hijabi basketball players between the ages of 16 and 30 were recruited to participate in this study. The data were collected through semi-structured interviews. A thematic analysis was adopted to analyze the data since this analysis method allows the researchers to interpret based on the data's in-depth examination. The study results showed that the negotiation of Islam identity was found in the ways of modifying their sports attires and behaviors in and out of the basketball fields. All of the participants saw their modifications as positive actions to integrate the Islamic values in their lives.

Tujuan penelitian ini adalah untuk mengetahui negosiasi identitas Muslim yang direfleksikan dari pengalaman para pemain bolabasket yang berhijab di Indonesia. Penelitian kualitatif ini menggunakan subjectivitas epistemologis. Enam pemain dari usia 16 hingga 30 tahun dipilih menjadi partisipan. Data dikumpulkan melalui interview semi struktural. Sedangkan analisa datanya merupakan analisa tematik karena dalam interpretasi data diperlukan pemeriksaan yang detail dan mendalam. Hasil analisa data menunjukkan bahwa negosiasi Identitas sebagai orang Islam dilakukan dengan cara memodifikasi kostum olahraga dan sikap mereka baik di dalam maupun di luar lapangan bolabasket.

el Harakah Jurnal Budaya Islam Vol. 22 No. 2 Tahun 2020 
Mereka memandang penyesuaian tersebut sebagai tindakan yang positif untuk menerapkan nilai-nilai Islam di dalam kehidupan mereka.

Keywords: hijab; identity negotiation; subjective experiences

\section{Introduction}

In Islam, the lives of Muslims, including clothing for women, are stated in the Quran. The Quran mentions the context of women's clothes a couple of times, as in Q.S.. Al-Ahzab: 53 and 59 and Q.S. An-Nuur: 31. The Quran vividly imposes general conditions of how Muslim women should wear their clothes: they should cover their awrah (parts of the body which must remain covered) except those that may be revealed, should not wear tight clothes, should avoid wearing flashy clothing or clothing that is too thin or revealing and from which a woman's body can be seen through, should not make humps, and should not perform in any distracting appearance.

There are various terms related to Muslim women's clothing, such as headscarves, robe, veil, hijab, khimar, niqab, jilbab, abaya, and buqa (Wardiani, 2019). Among those terms, the hijab is used in representing Muslim women's clothing because it sounds more global and more commercial nowadays. All of that serves to cover Muslim women's bodies; several definitions could be addressed to describe the hijab. Literally, the hijab means to cover or curtain, which is functioned to conceal something from being seen by others (Addwesh, 2000). It is used to protect Muslim women's awrah, especially after puberty. Scientifically, the hijab refers to the procedures of how to wear an appropriate dress following the guidance of Islam (Fakhruroji \& Rojiati, 2017). Therefore, Muslim women should wear a hijab in all walks of life, including in the arena of sports.

Sport is defined as human activities involving physical exertion done to perceive health and fitness, measurable achievements, or competition (Tomlinson, 2010). As this activity includes physical work, physical skills are essential. Islam underpins sports' urgency for both men and women equally as there is no prohibition for women to do sports in the Quran. Even there are some hadiths explicitly describe that women are allowed to do sports; one such instance is: "The prophet raced with me, and I beat him." (Sunan Ibn Majah). The hadith narrates that Aishah raced with her husband, the Prophet. The word "race" here could be interpreted as the competition, in which women are also allowed to join sports for competition purposes. 
Besides, many scholars also mention some benefits of sports activities and also why sports are evoked in Islam: to be healthy and fit, to make time for leisure, and to be ready for war (Isard, 2015). Sports activities are also believed could increase the level of physical and mental fitness of individuals and healthy recreational activity.

In the era of modernization, Muslim women's participation in sports has been brewing loudly. In this context, the hijab has gained dual meanings: it does not consist of the practice of Islamic faith only but also enlarges the function as an indicator of social class, lifestyle, and status (Deniz, 2014). However, Muslim women athletes' participation percentage is significantly lower than that of other women athletes (Laar et al., 2019). Those Muslim women athletes encounter a set of challenges that are not faced by non-Muslim women athletes. The challenges are related to clothing or dress code, facilities, lack of role models, parental approval, transport, the social side, communication, lack of women-only sessions, childcare, socio-economic differences, time, employment, environment, and information (Women's Sport, 2010).

Accordingly, clothing becomes the main challenge among Muslim women athletes to participate in sports. Those in Middle East countries face problems related to their tight dress during public places' physical activities. Differently, those in Western countries have to defend wearing their moderate clothes among the non-Muslim society. Meanwhile, those who are in South East Asia countries have those two issues at the same time. Furthermore, the hijab is banned from wearing in international sports competitions as it is considered a religious symbol that should not exist in the fields. Such symbols are perceived as harmful entities that can break the games (Hamzeh, 2017).

With the increasing numbers of Muslims worldwide, there were more cases where the skillful hijabi athletes banned from joining the competition because they refuse to remove their hijabs during the competitions. For instance, the Bahrain girls' basketball team was banned from competing at the Asian Youth Games in 2009, and the Iranian girls' youth national soccer team was banned from competing in the Youth Olympic Games in 2010. As many protests from any society levels, the International Weightlifting Federation, as the federation allowed hijabi players to cover their arms and legs, and the option of wearing hijabs during competitions started in 2011. By 2012, FIFA had also lifted its ban for women wearing hijabs during soccer games. In 2014, FIBA agreed to do a two-year trial period in which the hijabi athletes were able to wear hijabs and silk turbans during selected competitions. The 
turndown of the hijab ban just happened in October 2017. Unfortunately, FIBA's rules of the game do not clearly state the headscarves in describing women's basketball players' dress codes. Although hijabi basketball players are now allowed to join international basketball competitions, some still experience some challenges in the field. Indonesian hijabi basketball players might face more varied experiences than those from other countries since Indonesia is one of the Muslims-majority populated countries.

However, the experiences and the notion of hijab controversies in sports competitions would somehow reflect how the hijabi basketball players perceive their self-images. In general, the self-concept is the set of meanings they hold for themselves when they look at themselves. It is based on their observations of themselves, their inferences about who they are, based on how others act toward them, their wishes and desires, and their evaluations of themselves (Stets \& Burke, 2003).

There are many different concepts of selves, as there are other positions that the hijabi basketball players hold in a particular society and, thus, different groups who respond to themselves. Each hijabi basketball player has an identity for each of the other positions or role relationships in specific groups or societies. Thus, self as a basketball player is an identity, as is the self as a woman, self as Muslim, and self as any other myriad of possibilities corresponding to the various roles she might be in. The identities resemble the meanings one has. What does it mean to be an athlete? What does it mean to be a Muslim? What does it mean to be a woman? These meanings are the contents of the identities (Stets \& Burke, 2003).

The self-images building is very crucial in creating a sense of belonging and identity construction. Identities are formed and constructed across different discourses. It is continuously in change and transformation, not static, and remains to change based on the contexts or situations they belong to (Khalil, 2018). Enacting a role identity is always done concerning a corresponding counter-identity. Interaction still needs some degrees of coordination and compromise between individuals to achieve smooth role performances. It is known as negotiation (Stets \& Burke, 2003). Hijab can be, therefore, understood as an expression of the Muslim women athletes' identities. It relates to their personalities as individuals in or as part of the community they belong to (Jardim \& Vorster, 2003).

Moreover, it is also said that Muslim women's identities must reflect the Islamic values in their physical appearance. The physical appearance here 
could be seen from the way they wear their clothes. Besides, Muslim women's speech, attitude, and social interactions should also represent Islamic values (Benn, 2009).

Thus, exploring Muslim women's subjective experiences in wearing hijab is fascinating because its diverse frame of reference is worth investigating further. Comprehensively, this study wants to analyze the Islamic identity negotiation on the hijabi basketball players' basketball experiences in Indonesia. Many scholars have carried out some previous studies on Muslim women participation in sports. Those studies have mainly taken place about Muslim women in non-Muslim society or Western countries context and Muslim countries.

There are limited studies conducted in the Muslim - majority populated countries. One study was about the sports activities that demand high performances of Muslim women athletes in Indonesia and Malaysia. This study illustrated the top three high demand-sports among Malaysian Muslim women athletes: badminton (46.5\%), swimming (34.5\%), and athletics (27.6\%). In comparison, the sports that demand high-performance for Muslim women athletes in Indonesia were swimming (57.9\%), badminton (38.6\%), and volleyball (29.8\%) (Fitri et al., 2017). The next previous study was about Muslim participation in sport and physical activities in Muslim-majority populated countries (Hairiel et al., 2019). The study results reflected that Muslims should participate in sports and physical activities that accommodated the needs of practicing Muslims. These two studies discussed only the percentages of Muslim participation in all kinds of sport. Those previous studies had not involved identity of the athletes in a certain type of sports; therefore, this study would inherent new additional values in the fields.

\section{Method}

This study aimed to explore the basketball players' subjective experiences in wearing the hijab. Therefore a qualitative method was conducted from a subjectivist epistemological position. Subjectivism believes that knowledge is always collected from language, gender, social class, race, and ethnicity. A subjective epistemology recognizes that knowledge is valuable (Levers, 2013). Epistemology refers to how knowledge is collected. The subjectivist acknowledges that the researchers and the participants will play active roles in constructing the knowledge generated in the study (Lincoln et al., 2011).

Six hijabi basketball players between the ages of 16 and 30 were recruited to participate in this study. The participants were purposively selected among

el Harakah Jurnal Budaya Islam Vol. 22 No. 2 Tahun 2020 
the best players from different basketball clubs in East Java. They should fulfill the criteria of self-identify as being Muslim, actively playing in professional and amateur basketball competitions, and wearing hijab both in daily practices and every event of the competition. By considering the study's ethics, all participants were informed of the study's theme, scope, and objectives before the interview.

The data were collected through semi-structured interviews. This type of interview was chosen to allow the participants to share information and still had the freedom to express and say anything (Sparkes \& Smith, 2014). The interviews were developed to gain information related to the participants' past experiences and interpret their current point of view and future perspectives (Rosenthal, 2011). Hence, the questions were formatted to ask about their background, identity as hijabi basketball players, sport competitions experiences, and religion. The questions and answers in the interviews were in Bahasa Indonesia and recorded in audio recording.

A thematic analysis was adopted to analyze the data since this analysis method allows the researchers to interpret based on the in-depth examination of the data. Besides, this method is also flexible according to the sample size, data collection method, and theoretical approach (Braun \& Clarke, 2006). The flexibility allows the researchers to identify and select the data themes to contextualize them, since themes do not merely emerge from the data (Braun \& Clarke, 2006). In this method of analysis, there are six main phases to follow; they are: understanding the data, creating initial codes, searching for themes throughout the data, reviewing all of the themes, defining and naming themes, and finally producing the reports (Braun \& Clarke, 2006).

In this study, transcribing the interviews was done by transcribing the interviews, reading the transcription multiple times until all contexts were captured, and then translated into English. All the transcriptions were then uploaded into NVivo to be coded. After that, these codes were generated based on Islam's religious factor into some big themes. They were reviewed thoroughly by comparing the similarities and differences among them to identify the connections with the participants' experiences. This stage was also enabling the process of expanding and narrowing down the themes. As the themes were finalized, the participants' subjective experiences would be incorporated with the embodied faith of Muslim women identity (Benn, 2009). 


\section{Findings and Discussion}

It is essential to describe the profiles of the participants as it would also somehow impacts their perspectives. The profiles are about their ages, education, profession, basketball clubs, kinds of basketball competitions they join, and age they start wearing the hijab. It was revealed that three of them were professional basketball players, and the other, there were amateur ones. As requested by the participants, the names would be in initials, and a city would represent the clubs' names.

The first participant was ENAP. She was 20 years old and a basketball player from a basketball club in Surabaya. She was taking her undergraduate study. She was. She started wearing a hijab about four years ago and started playing basketball since she was in her junior high school, about seven years ago. It means that she started to play basketball three years before she started to wear a hijab. As a professional basketball player, she has played for the Province level competitions since she was in the high schools until now. Her team also became the winner, the runner up, and the third winner in the competitions.

The second participant was NRS. She was 26 years old, and now she has already worked in an office but is still an active basketball player. She has started to play basketball fifteen years and started to wear a hijab six years ago. As a professional basketball player, she has played in many competitions, started from senior high school competition, province competition, national competition, and international competition. Her highest achievement was becoming the runner up in one of the South East Asia basketball competitions.

The third participant was RAH. She was a 30-year-old woman who right now is still active playing for basketball competitions. She was a lecturer in the Department of Economy in one of the private universities in Indonesia. She has played basketball for fifteen years. The first time she played basketball, she has already worn the hijab. Eight years ago, she started becoming a professional basketball player. As a national team of basketball, she has joined many national and international competitions. She was also a $3 \times 3$ player representing Indonesia.

The fourth participant was LSK. She was 16 years old and studied in senior high school. As a member of a basketball club in Surabaya, she has started playing basketball for about eight years, since she was in the third grade of elementary school. Three years later, after she was in the first grade of senior high school, she started to wear a hijab. It indicates that her basketball carrier was started three years before she started wearing the hijab.

el Harakah Jurnal Budaya Islam Vol. 22 No. 2 Tahun 2020 
As an amateur basketball player, she has been recruited in the regional team and played for the regional competitions a few times. Her teams won some competitions as the runner up and third winner.

The fifth participant was HBL. She was a 23-year-old basketball player from one of the basketball clubs in Gresik. Though she has already worked part-time, she is still an active basketball player. She has joined a school basketball team since she was in junior high school. In the last four years, she has worn a hijab. As an amateur basketball player, she has just played in regional competitions. Her team won two of the competitions as the runner up. The last participant was YAN. She was 16 years old and a senior high school student. She has just started playing basketball for four years, and she decided to wear a hijab a year ago. As an amateur basketball player, she played in high school competitions and regional competitions. Her team never won the competition.

The following parts would discuss the Islamic identity negotiation in two themes: sport attires modification in sports spaces and behavior modification in sports spaces. The negotiation was based on the hijabi basketball players' subjective experiences.

\section{Sports Attires in Sport Spaces}

The issue of clothing in sports does not appear clearly in Indonesia as it is one of the Muslims - majority populated countries. The aforementioned discussion says that wearing a hijab is obligatory for Muslim women, as stated in the Quran. In contrast, in Indonesia, the hijab debate is between the Muslim women who wear and who do not wear a hijab (Wardiani, 2019). Because not all Muslim women in Indonesia wear hijabs, it then gives the Muslim women basketball players choices to wear hijab. This statement is also supported by research saying that wearing a hijab among Muslim women reflects the variation of how they practice Islam and more related to a personal choice (Nakamura, 2002). The options in wearing a hijab here then impact their sports attires during the competitions. The basketball players who decided to wear hijabs, the participants of this study, wear the sports attires that should reflect the Islamic values, making them wear the attires different from the standard ones. The theme of sport attires here would be broken down into smaller themes on wearing hijabs and dress code challenges.

In this case, all six hijabi basketball players chose to wear hijabs while playing basketball. All of them had the same perspectives on why they wear 
hijab because of Islam. It reflects that all of them see Islam in the same way that Islam does ask Muslim women to cover their bodies. Moreover, their participation in basketball games and competitions is also based on the Islamic hints, as it was stated that Muslims should move their bodies actively, such as in sports (Hairiel et al., 2019). Besides, they also have additional reasons why they wear hijabs, to strengthen their faith, such as from families.

$\mathrm{RAH}$, for example, wore hijab since she was a kid, years before she started playing basketball, and stated:

"I started to wear hijab since I was a kid. My family introduced me to hijabs every time we went out of the house. So, the hijab is not just compulsory but also a habit for me. Now, I understand that wearing a hijab is one of the steps to fulfill God's commands, and I would not change my hijab for anything else in this world". (RAH, 30).

"Doing sport is very important for Muslims, as it is one of the Sunnah in Islam to keep our bodies to be fit and healthy. Fortunately, I love basket very much, and I do it not just for sport but also for my passion". (RAH, 30).

It could be revealed that RAH chose to wear hijab as she was growing up in a religious family, and it taught her that wearing a hijab was not a choice, but a command, as stated in the Quran. She also argued that doing sport was one of the ways to follow the Sunnah in Islam. She loved being a Muslim woman and showing her Muslim identity by wearing a hijab and playing a sport, and basketball was her choice. For her, there was no reason not to wear a hijab on certain occasions, including playing basketball.

NRS also discussed how her adherence to modesty Islamic values strengthens her faith in wearing a hijab, including when she had to play in international competitions.

"I love Islam, and I want to be a good Muslim woman. Therefore, I follow what is commanded in the Quran that Muslim women need to cover their awrah. I want to be a better Muslim woman by following my religious rules. Wearing my hijab also shows my identity as a Muslim, and I want people to recognize it, especially when I play in other countries." (NRS, 26).

When she decided to cover up, she wanted to show that her modest clothes were her identity as a Muslim woman. People needed to know that covering up was not an awful thing to do in playing sports, especially basketball. Covering up the body was also one way to show her faith in the religion, in this case, Islam.

All those hijabi basketball players wore hijab because they wanted to follow what was commanded in the Quran, but there was one of them, YAN, who added that she wore hijab because she wanted to wear what Muslim women wear:

el Harakah Jurnal Budaya Islam Vol. 22 No. 2 Tahun 2020 
"I know that we (Muslim women) must wear hijab because our religion asks women to cover their bodies and heads. Many Muslim women in Indonesia also wear hijabs. Playing basketball and wearing a hijab, why not?" (YAN, 16).

This statement showed that YAN wore her hijab not only because of her piety but also of the trend. She was influenced by the Muslim atmosphere in Indonesia, where most Muslim women wore hijabs. The hijab atmosphere contributed to the construction of her identity as a Muslim woman.

Furthermore, their dress codes should support the decision to wear a hijab and modest clothing (Nakamura, 2002). When the dress codes were stipulated in uniform, some competitions did not provide the pants and long sleeve shirts for the players, so they needed to modify their dress codes. Meanwhile, sports uniform is an essential aspect of creating team identities (Slater et al., 2015).

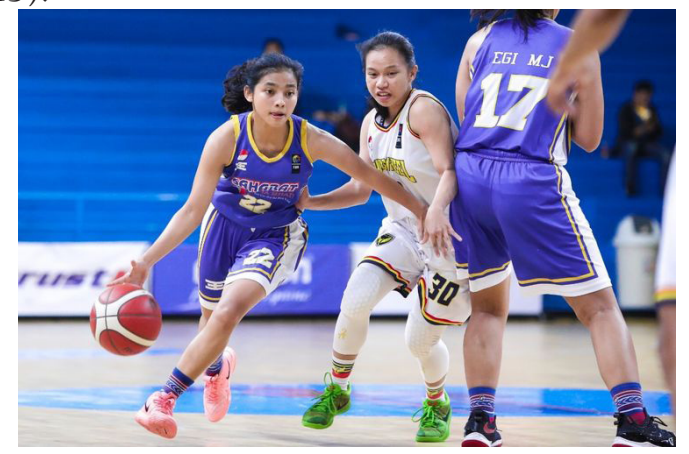

Figure 1. Standard Sports Attire for Female Basketball Players

Source: https://www.kompas.com/skola/read/2020/05/27/141754069/peraturanpermainan-bola-basket

All six hijabi basketball players mentioned that the sports attires were the challenge in terms of uniforms. Four of them (ENAP, NRS, RAH, and $\mathrm{HBL}$ ) had the same opinion. They said that the attires might be a problem when the uniform only shorts and tank top jersey, which is the standard uniform for basketball players. The above figure is the standard sports attire for female basketball players.

HBL shared an incredible experience related to her sports attire:

"I once was called by the referee to change my undershirt because the color did not represent the color of my team's uniform, or else, I should take it off. The color of the uniform was yellow, but at that time, I wore a white undershirt. My uniform was different from the team, and I needed to change it to yellow because that was the idea of uniform should be uniformity. Well, to me, it was not relevant. I could not find any yellow long sleeve undershirt, so I chose not to play. I would not take my long sleeve undershirt." (HBL, 23) 
From her experience, it was shown that her faith was not defeated by the prestigious competition or the referee's rules. She tried to follow the instruction by looking for a yellow undershirt, but she could not find any. Therefore, she decided to leave the competition rather than took off her unmatched undershirt. She tried to show her identity as a Muslim woman who needs to cover up the awrah. Her sports attire was identical with the following figure.

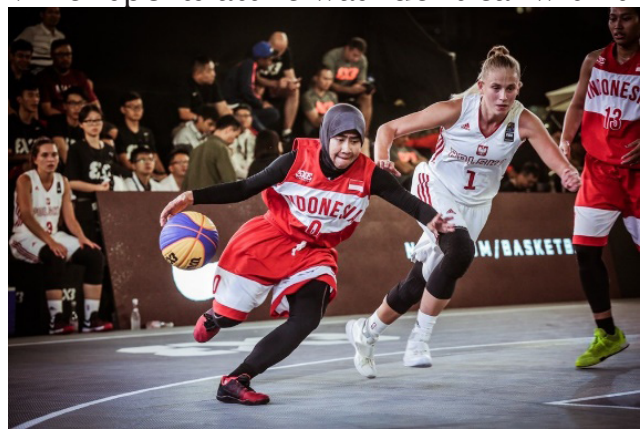

Figure 2. Sports Attire with a long undershirt and long undershorts for Hijabi basketball player

Source: https://www.mainbasket.com/r/501/perjuangan-raisa-aribatul-hamidahmembuka-jalan

Of those who wore hijabs, NRS felt that she could not freely move when she wore the uncomfortable hijab fabric, but she insisted on wearing such kinds of hijabs. In line with this, LSK and YAN also shared their experiences in the first year wearing hijabs. They said their hijabs limited their movements during the competitions, such as when they did dribbling, passing, and shooting the balls. Additionally, LSK said, "I used to tie it up so it would not get in my way when I shoot my ball."

Although each of them had various ways of negotiating their Islamic identities, they all put significant efforts to keep the identity as Muslim women. It could be revealed that all those six players continued to wear a hijab in every competition. They all agreed that they always learned to find out the most comfortable sport attires without disobeying the Islamic rules, such as wearing long-sleeved undershirts, loose pants, and comfortable hijabs. They also admitted that finding sport attires for Muslim women nowadays is getting easier. Since many famous brands provide sport attires for Muslim women, the chances to play basketball for hijabi open widely, such as when Nike Pro Hijab starts to provide apparel, footwear, and equipment for FIBA Women's Basketball World Cup in 2017 (Cook, 2018). 
The issues on sports attire are always getting more severe in international competitions, a mixed religion society. RAH shared her experience with hijab banning.

"I was appointed as one of the national team members for Indonesia in SEA GAMES 2015, but before I could fight for my country, the SEA GAMES committee deleted my name from the team because I wore hijab. According to the rules by FIBA, the basketball players were not allowed to wear long pants, long sleeve shirt, and headcover. I was very disappointed. Even though they deleted my name, they could not stop me from wearing a hijab nor play basketball. Since then, I decided to plead, with two basketball players from the United States, against the FIBA rules related to Muslim women's sports attire. So, for all hijabi women, the hijab is not a reason to fail you." (RAH, 30).

Here, RAH could not meet her religious expectation because the committee had shifted the roles of hijab from an entity representing Muslim women's identity into a differentiating tool between hijabi basketball players and the teammates. This finding was also supported by the research results saying that sports uniform has changed into an active symbolic tool of differences in sports area (Khalil, 2018).

\section{Behavior Modification in Sport Spaces}

It is essential to underline that all of the participants saw their behavior modifications as positive actions. They realized that such modifications were needed to integrate Islamic values as they attempted to behave in Islamic ways. These behavior modifications were parts of the Islamic identity negotiation as hijabi Muslim women and basketball players. NRS shared her experience when she started to wear the hijab:

"It is still clear in my memory that when I started wearing a hijab, I felt so blessed and appreciated because my teammates and the boy's team give more respect. As a reply, I wanted to show them that I am the one that can keep that pride, and I felt a feeling that I never found before... hmhmhm... maybe it is new energy to practice more and to prove that hijabi player could jump high". (NRS, 26).

By wearing a hijab, she started being a visibly Muslim woman and concerned that more people paid respect. Therefore, she wanted to prove that she could be a good Muslim woman and a good basketball player. Her new physical appearance motivated her to do more positive actions, such as to practice harder than before.

All of the participants also agreed that the hijab helped them control their emotions during the competitions. LSK stated:

"As my basketball career had just started, I needed to learn more about how to control my emotions and strategies. I used to be rude and demanding in playing. Hijab taught me to be calm. Since I wore hijab.... I think that I could handle my behavior in the 
field. I played sportively but still gave some spaces to other players so I would not hurt them. (LSK, 16).

As evidenced by this sort of interview, she tried to manage her anger when playing basketball. She knew that she still learned how to control her motion, but she put herself as a basketball player that could modify her behavior to represent Islam. Suppressing anger is also in line with what Islam asks to do, as it is written "O believers! Seek comfort in patience and prayer. Allah is truly with those who are patient." (Q.S.. Al-Baqarah: 153). This result of the study is also supported by one of the researches that she was seen as herself and the Muslim in general by showing her anger. Therefore, she realized that she had to keep her manner (Khalil, 2018).

The five participants also talked about their needs to do behavior modification in representing Islam. HBL shared her experience:

As an ambitious girl, I wanted to make many scores and win the competitions, but I would get furious and yell to my teammates when my team lost. I also often cried a lot and blamed my teammates for not performing their best. Although I still learn how to manage it, I have become more mature and believe that not all competitions ended with a victory. Hijab prevented me from doing such negative things". (HBL, 23).

Here, one of the hijabi basketball players described the role of wearing a hijab in her basketball carrier. Hijab has kept her to modify her behavior and behave and point of view. By wearing the hijab, she attempted to behave in ways that were in line with Islam's identity, such as not being selfish by blaming the teammates for losing the competition. She also tried to understand that winning a competition was not an absolute thing that should happen every time they performed.

Then, they also said that particular audiences amplified distinguished modification. ENAP explained the situation:

"When most of the audiences are non-Muslim, I am definitely would play carefully. I usually try to show my best as an athlete and as a Muslim woman". (ENAP, 20).

ENAP underlined that she was becoming more aware when interacting with people who did not know Islam very well. She thought that it was needed to modify her behavior to give a positive impression of Islam. It was vital for her to perform the best identity as a Muslim woman. The modification was also possible when there was a male presence among them. As RAH shared:

"It is a bit awkward to have male coaches or referees. I try to minimize my physical contact with them, such as handshaking or hugging. As a Muslim woman, I know that my religion suggests men and women who are not mahram to lower their sights and avoid physical contacts." (RAH, 30).

el Harakah Jurnal Budaya Islam Vol. 22 No. 2 Tahun 2020 
Although it was a habit to shake hands with male coaches or referees at the end of the competitions, she just greeted them and prevented herself from having any physical contact. This behavior modification represents the values of Islam about how men and women should keep their relations. Another research gave a different perspective that women prevented from initiating physical contact with male coaches or referees to avoid getting an adverse judgment from other Muslims (Khalil, 2018).

Behavior modification here refers to their choices to behave appropriately based on Islamic values. Islamic values shape their behavior, so they feel the urge to represent their identities as Muslims, including in the arena of competitions. They voluntarily put themselves to moderate their behavior to represent Islam positively. It is not about making others impressed with them, but about how they could obey the Islamic rules and guidance.

\section{Conclusion}

Hijabi basketball players in Indonesia face unique challenges in the fields, especially in international competitions. However, none of the participants considered opening their hijab to satisfy the basketball rules. Some of them even fought the system by sounding petitions for turning down the hijab banning in basketball. All of them would choose to leave the basketball competitions or even participating in any competition rather than removing their hijab or one of the Muslim women's sport attires. They also modify their ways of behavior in and out of the field. Some of them even succeed in removing their bad habits and adjusting to any new spaces.

A brief review of the representations of hijabi basketball players' subjective experiences above shows the existence of Islamic values and principles in identity negotiation. The negotiation is integrated into their modification of sport attires and behavior. They see their modifications as positive actions and are needed to represent their identity. These negotiations affirm their identity as hijabi Muslim women who also basketball players. They always put Islam as the fundamental reason to negotiate their identities so that there is a very strong chain between the hijabi basketball players' subjective experiences and Islam that could be separated.

\section{References}

Addwesh, A. 2000. Hijab. King Fahd National Library Cataloging -in-Publication Data. http://www.islamicbook.ws/english/english-016.pdf 
Benn, T. 2009. Muslim Women in Sport: A Researcher's Journey to understanding Embodied faith. International Council for Sports Science and Physical Education, Bulletin, 55, 48-56. https://research.birmingham. ac.uk/portal/en/publications/modelling-of-strain-energy-harvesting-inpneumatic-tyres-using-piezoelectric-transducer(05aaffdd-bd6d-47d2-8aba6a6eb0ef1ae3)/export.html

Braun, V., \& Clarke, V. 2006. Using thematic analysis in psychology Virginia. Qualitative Research in Psychology, 2(3), 77-101. https://doi. org/10.1191/1478088706qp063oa

Cook, K. J. 2018. Uncovering the Evolution of Hijabs in Women's Sports. The Graduate Review, 3, 62-67. http://vc.bridgew.edu/grad_revhttp:// vc.bridgew.edu/grad_rev/vol3/iss 1/13

Deniz, E. 2014. Veiling fashion, consumption culture and identity: A qualitative analysis for interpreting the veiled Turkish women's changing clothing practices. In içinde Proceedings of SOCIOINT14-International Conference on Social Sciences and Humanities (pp. 8-10).

Fakhruroji, M., \& Rojiati, U. 2017. Religiously fashionable: Constructing identity of urban Muslimah in Indonesia. Jurnal Komunikasi: Malaysian Journal of Communication, 33(1), 199-211. https://doi.org/10.17576/ jkmjc-2017-3301-14

Fitri, M., Sultoni, K., Salamuddin, N., \& Harun, M. T. 2017. Preface: International Conference on Recent Trends in Physics (ICRTP 2016). IOP Conf. Series: Materials Science and Engineering 180 012213. https:// doi.org/10.1088/1757-899X/180/1/012213

Hairiel, B., Jani, M. H., \& Diah, N. M. 2019. Sports and Physical Activities In Islam : Reflections Of Muslim. Al-Sirat, 1(March), 88-99. https:// doi.org/10.13140/RG.2.2.25661.72160

Hamzeh, M. 2017. FIFA's double hijabophobia: A colonialist and Islamist alliance racializing Muslim women soccer players. Women's Studies International Forum, 63, 11-16. https://doi.org/10.1016/j.wsif.2017.06.003

Isard, R. 2015. Muslim Women in Sport | Soccer Politics / The Politics of Football. http://sites.duke.edu/wcwp/research-projects/middle-east/muslimwomen-in-sport/

el Harakah Jurnal Budaya Islam Vol. 22 No. 2 Tahun 2020 
Jardim, G. L., \& Vorster, J. M. 2003. Hijab and the construction of female religious identity. In Die Skriflig/In Luce Verbi, 37(2), 271-287. https:// doi.org/10.4102/ids.v37i2.469

Khalil, A. A. A. 2018. In and Out: Exploring Inclusion and Alienation within the Sport Experiences of Hijabi Athletes in Ontario.

Laar, R. A., Shi, S., \& Ashraf, M. A. 2019. Participation of Pakistani female students in physical activities: Religious, cultural, and socio-economic factors. Religions, 10(11). https://doi.org/10.3390/rel10110617

Levers, M. J. D. 2013. Philosophical paradigms, grounded theory, and perspectives on emergence. SAGE Open, 3(4). https://doi.org/10.1177/2158244013517243

Lincoln, Y. S., Lynham, S. A., \& Guba, E. G. 2011. Chapter 6 _ Paradigmatic Controversies, Contradictions, and Emerging Confluences, Revisited _ Queensland University of Technology. In Y. S. L. Norman K. Denzin (Ed.), The Sage handbook of qualitative research (4th ed, pp. 97-128). Sage. https://qut.rl.talis.com/items/5F50F05B-907A-515C-DBC1OBFD5779FA72.html

Nakamura, Y. 2002. Beyond the Hijab: Female Muslims and Physical Activity. Women in Sport and Physical Activity Journal, 11(2), 21-48. https://doi. org/10.1123/wspaj.11.2.21

Rosenthal, G. 2011. Biographical Research. In C. Seale, G. Gobo, J. Gubrium, \& D. Silverman (Eds.), Qualitative Research Practice (pp. 49-65). Sage. https://doi.org/10.4135/9781848608191.d7

Slater, M. J., Barker, J. B., Coffee, P., \& Jones, M. V. 2015. Leading for gold: social identity leadership processes at the London 2012 Olympic Games. Qualitative Research in Sport, Exercise and Health, 7(2), 192-209. https:// doi.org/10.1080/2159676X.2014.936030

Sparkes, A. C., \& Smith, B. 2014. Qualitative Research Methods in Sport, Exercise and Health From Process to Product. Routledge. https://www.routledge. com/Qualitative-Research-Methods-in-Sport-Exercise-and-Health-FromProcess/Sparkes-Smith/p/book/9780415578356

Stets, J. E., \& Burke, P. J. 2003. A sociological approach to self and identity. Handbook of Self and Identity, 128-152. http://wat2146.ucr.edu/ papers/02a.pdf 
Tomlinson, A. 2010. A Dictionary of Sports Studies. Oxford University Press. https://doi.org/10.1093/acref/9780199213818.001.0001

Wardiani, S. R. 2019. Muslimah's Clothing Brand, Identity, and Myths in Barthes Semiotic Study. El Harakah (Terakreditasi), 21(1), 83-104. https:// doi.org/10.18860/el.v21i1.6188

Women's Sport and Fitness Foundation and Sporting Equals. 2010. Muslim Women in Sport. 
